\title{
Copper Phytoextraction and Phytostabilization by Brachiaria decumbens Stapf. in Vineyard Soils and a Copper Mining Waste
}

\author{
Robson Andreazza ${ }^{1,2 *}$, Leandro Bortolon ${ }^{3}$, Simone Pieniz ${ }^{4}$, Flávio A. O. Camargo ${ }^{1}$, \\ Elisandra Solange Oliveira Bortolon ${ }^{3}$ \\ ${ }^{1}$ Department of Soil, Federal University of Rio Grande do Sul, Laboratory of Soil Microbiology, Porto Alegre, Brazil; ${ }^{2}$ Center of \\ Engineering, Federal University of Pelotas, Pelotas, Brazil; ${ }^{3}$ EMBRAPA-National Research Center of Fisheries, Aquaculture and \\ Agricultural Systems, Palmas, Brazil; ${ }^{4}$ Department of Technology and Food Microbiology, Federal University of Rio Grande do Sul, \\ RS, Porto Alegre, Brazil. \\ Email: ${ }^{*}$ robsonandreazza@yahoo.com.br
}

Received July $27^{\text {th }}, 2013$; revised August $27^{\text {th }}, 2013$; accepted September $7^{\text {th }}, 2013$

Copyright (C) 2013 Robson Andreazza et al. This is an open access article distributed under the Creative Commons Attribution License, which permits unrestricted use, distribution, and reproduction in any medium, provided the original work is properly cited.

\begin{abstract}
Brachiaria decumbens is a high biomass plant with great potential for phytoremediation of copper-polluted soils. The current study aimed to evaluate $B$. decumbens plants for phytoextraction and phytostabilization use in two different copper contaminated vineyard soils and a copper mining waste. Also, the macro and micronutrients uptake were evaluated after plants growth in copper contaminated soils. B. decumbens was cultivated in two vineyard soils (Inceptisol and Mollisol) and a copper mining waste for 47 days of growth in greenhouse. Then, B. decumbens's nutrient uptake was evaluated, and it's potential application in phytoremediation techniques for the phytoextraction and phytostabilization of copper contamination. B. decumbens exhibited high levels of biomass production at contaminated soils and no negative effect on macronutrients uptake was found. Copper contaminated soils affected micronutrients uptake by Brachiaria plants. This Brachiaria specie showed high potential on copper phytoextraction with accumulation of copper concentrations in the shoots and roots of 70 and $585 \mathrm{mg} \cdot \mathrm{kg}^{-1}$ of dry mass, respectively, in the vineyard Inceptisol soil, after 47 days of growth. Mollisol soil and copper mining waste also exhibited high copper concentration in the biomass in the entire plant with 371 and $466 \mathrm{mg} \cdot \mathrm{kg}^{-1}$, respectively. Although Brachiaria exhibited low levels of translocation factor for copper, this specie showed high potential for copper phytoextraction on Inceptisol, Mollisol and copper mining waste with 1900, 1156 and $1363 \mathrm{~g} \cdot \mathrm{ha}^{-1}$ of copper, respectively. In summary, B. decumbens plants showed high potential for copper phytoextraction and phytostabilization of copper on contaminated vineyard soils and copper mining waste.
\end{abstract}

Keywords: Soil Pollution; Soil Remediation; Nutrient Uptake; Bioremediation

\section{Introduction}

Environments contaminated with heavy metals have been increased in all countries by human activities [1,2]. Agricultural practices increase heavy metal pollution by addition of manufactured products such as sprays and fertilizers, and non-controlled discards of heavy metal content in the wastes [3]. Copper mining operations, generally, generate high quantities of wastes with high levels of copper [4]. Remediation of these contaminated sites is required to reduce contaminations of organisms including humans. Phytoremediation is an efficient alternative to reduce the contamination of environment with heavy

${ }^{*}$ Corresponding author. metals, reducing the contamination to adjacent sites such as soils and watercourses.

Phytoextraction, a phytoremediation process, is a costeffective plant-based technology to remove heavy metals from the environment $[5,6]$. Studies to select efficient plants are necessary, because plants have different potential for phytoextraction among species and environments [7], being necessary studies to evaluate the adaptability and efficiency to each specific situation. Thus, the interest for phytoremediation of contaminated areas with heavy metal is increasing over the years and throughout the world to reduce the negative environmental impact [716].

Another strategy of phytoremediation, is the phytosta- 
bilization, which uses plant to immobilize heavy metals in soil through absorption, roots accumulation, adsorption onto roots, or precipitation within the root zone of plants [6]. This technique is used successfully for heavy metals [17-20] and organic amendments [21]. This process can play an important role in the vineyard soils contaminated with copper, due to these areas are usually located in steep mountains with sandy soils, subjected to erodibility, promoting high soil losses by surface runoff.

Brachiaria decumbens is species often used, primarily as a pasture, and also it has been used as either cover crop or green manure to protect the soils from the surface runoff of soil [22]. Moreover, this species is a plant with high biomass production [22], and it is produced widely throughout the world [23]. B. decumbens is well adapted to infertile acid soils $[23,24]$, and can be used in a wide range of soils. Currently, studies on phytoremediation of soils polluted with heavy metals, using $B$. decumbens have showed high growth capacity with toxic levels of $\mathrm{Pb}, \mathrm{Cd}$ and $\mathrm{Zn}$ and also bioaccumulation with heavy metals in the phytomass [12]. Although, there is a paucity of studies regarding copper phytoextraction and phytostabilization of copper contaminated soils such as vineyards and copper mining wastes using $B$. decumbens. Thereby, the aim of this study was to evaluate the capacity of $B$. decumbens for copper phytoextraction and phytostabilization, and to analyze macro and micronutrient uptake after plant growth in copper contaminated soils.

\section{Experimental}

\subsection{Site and Experiment Characterization}

A greenhouse experiment was conducted with samples from topsoil $(0-20 \mathrm{~cm})$ layer taken from two vineyard soils contaminated with copper, and a copper mining waste from Southern Brazil. Two soils (Inceptisol and Mollisol) were collected from vineyards at Brazilian Agricultural Research Corporation located in Bento Gon-

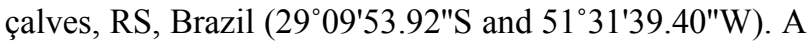
native soil from a native forestry area located near to the vineyards, and a copper mining waste from a mine in Caçapava do Sul, RS, Brazil $\left(30^{\circ} 29^{\prime} 43.48^{\prime \prime} \mathrm{S}\right.$ and $53^{\circ} 32^{\prime} 37.87^{\prime \prime} \mathrm{W}$ ) were also used. The two vineyard soils were located in a steep terrain with 40 -year-old vineyards. The soil contamination still increasing by constantly addition of sprays copper content to control leave diseases. These two types of soils are the most representative soils used to vineyards in Southern Brazil (Figure 1). Copper mining waste is located in a widely area filed with mining waste from copper mining located in Caçapava do Sul, South of Brazil (Figure 1). Mining waste area is an unstructured residue disposed in large plan area, originating an extreme impacted environment for living or

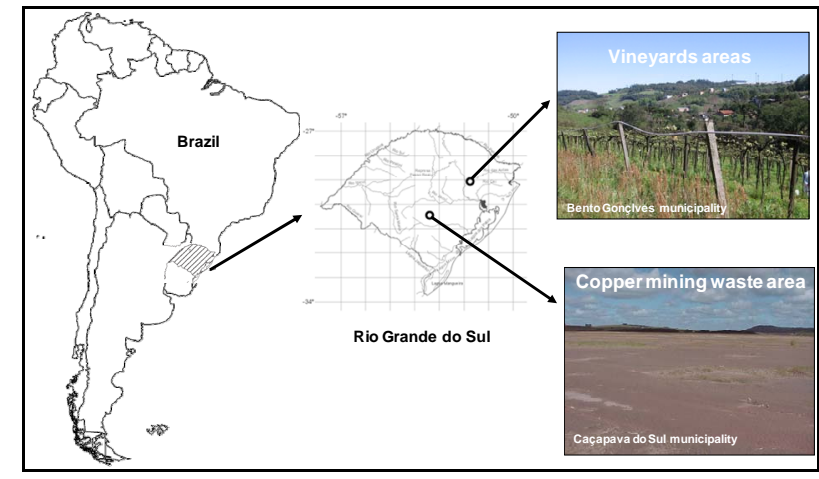

Figure 1. Location of the vineyard areas in the Bento Gonçalves city, and copper mining waste in the Caçapava do Sul city, both cities in the Rio Grande do Sul State (RS) in Brazil country in South America.

ganisms with low nutrient availably and high copper concentrations.

\subsection{Soil Characterization}

All soil samples were air dried for two weeks, ground and sieved $(3 \mathrm{~mm})$ prior to physical-chemical analyses [25]. Soil analysis showed the extractable copper (extracted with $0.1 \mathrm{M} \mathrm{HCl}$ ) was $3.8,207,142$ and 576 $\mathrm{mg} \cdot \mathrm{kg}^{-1}$ in the native soil, Inceptisol, Mollisol and copper mining waste, respectively. Based on the nutrient recommendations for crops from southern of Brazil, soil samples $(1 \mathrm{~kg})$ were amended with nutrient solution consisting of $4.5 \mathrm{mg} \mathrm{B}\left(\mathrm{H}_{3} \mathrm{BO}_{3}\right)$ and $25 \mathrm{mg} \mathrm{S}\left(\left(\mathrm{NH}_{4}\right)_{2} \mathrm{SO}_{4}\right)$ and mixed. Other nutrients were classified as "adequate" and were not supplied. Soil $\mathrm{pH}$ was adjusted to 6.5 using $\mathrm{CaCO}_{3}$.

Five replicates of $1 \mathrm{~kg}$ each were placed into $700 \mathrm{dm}^{3}$ plastic pots. Deionized water was then added to the subsamples to bring the soil up to $80 \%$ field capacity water content and was maintained during the study period. Four soil treatments were tested: native soil (control); Inceptisol; Mollisol and copper mining waste ( $40 \%$ of native soil and $60 \%$ of copper mining waste).

\subsection{Cultivation of Plants for Copper Phytoremediation, Harvest and Analysis}

Copper phytoremediation was evaluated with three plants per pot of Brachiaria pasture (Brachiaria decumbens Stapf.) were maintained in each pot. At 15 and 30 days after seeding, $30 \mathrm{mg} \mathrm{N} \mathrm{g}^{-1}$ soil were sprinkled into the pots. The pots were watered during the growth period to maintain the soil water content near $80 \%$ of field capacity. After 47 days, shoots were harvested and immediately measured for height, wet mass and dry mass. Height was determined measuring the main stem from the base to the tip of the Brachiaria decumbens plants. 
Shoots were then dried at $60^{\circ} \mathrm{C}$ for $72 \mathrm{~h}$ and weighed. The soil-root system was measured for the wet mass weight and dry mass weight. After, wet mass was measured roots of each plants were separated by washing with deionized water, dried at $60^{\circ} \mathrm{C}$ for $72 \mathrm{~h}$, and weighed for further analysis.

The nutrient concentration in the dry matter of the shoots and roots were determined [26]. Nitrogen concentration was determined after digestion with concentrated sulfuric-peroxide by steam distillation, and quantification by titration. The concentration of the macronutrients $(\mathrm{P}$, $\mathrm{K}, \mathrm{Ca}, \mathrm{Mg}$ and $\mathrm{S})$ and micronutrients $(\mathrm{Cu}, \mathrm{Zn}, \mathrm{Mn}, \mathrm{Na}$ and $\mathrm{Fe}$ ) were determined following digestion in concentrated nitric-perchloric acid by Inductively Coupled Plasma-Optical Emission Spectrometry.

The translocation factor (TF) of $\mathrm{Cu}, \mathrm{Zn}, \mathrm{Fe}, \mathrm{Mn}$ and $\mathrm{Na}$ from the root to the shoot and the bioconcentration factor (BCF) of $\mathrm{Cu}$ were calculated as follows [27,28].

$$
\mathrm{TF}=[\text { Metal }] \text { shoot } /[\text { Metal }] \text { root }
$$

where [Metal]shoot is the concentration of the metal in the shoots, and [Metal]root is the concentration of the metal in the roots.

$$
\mathrm{BCF}=[\text { Metal }] \text { shoot and root } /[\text { Metal }] \text { soil }
$$

where [Metal]shoot and root is the concentration of metal in the shoots and the roots, and the [Metal]soil is the concentration of the metal in the soil.

\subsection{Statistical Analysis}

The experimental design in this study was randomized in a complete block with five replicates. Statistical analysis was conducted with ANOVA. When a significant difference was observed between treatments $(\mathrm{P} \leq 0.05)$, multiple comparisons were performed with the Tukey test.

\section{Results}

\subsection{Plant Growth}

Brachiaria decumbens exhibited a high level of growth potential (59 cm of height) in the Mollisol vineyard soil, which is contaminated with copper, when compared with the native soil (76 cm of height), without copper contamination (Figure 2). Growth of Brachiaria decumbens was 3-fold lower in the Inceptisol (vineyard soil) and copper mining waste, than the plants cultivated in the native soil with values of 24 and $25 \mathrm{~cm}$, respectively (Figure 2).

Brachiaria decumbens plants produced high levels of biomass of the wet and the dry matter, after 47 days of growth in copper contaminated soils (Figures 3(a) and (b)). Brachiaria grown in the Mollisol soil exhibited the highest production of the dry biomass in the shoots and

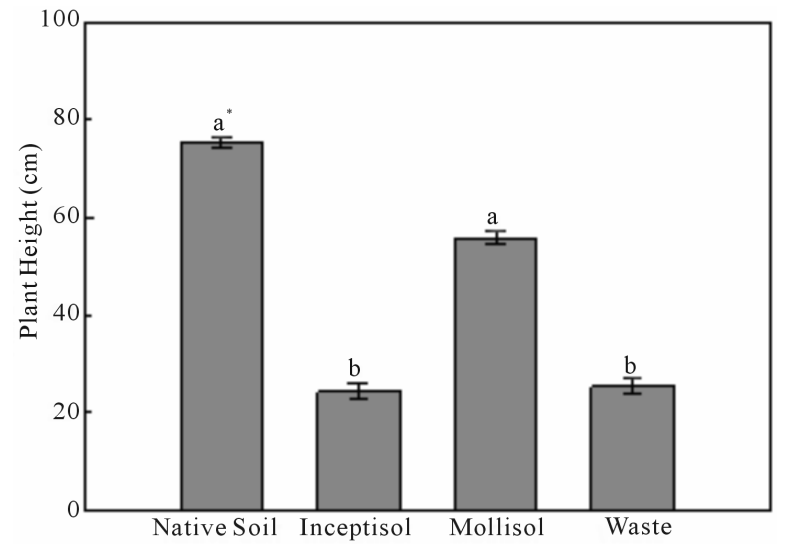

Figure 2. Plants height of Brachiaria decumbens after 47 days growing in different copper contaminated soils: Native soil (Control); Inceptisol; Mollisol and copper mining waste (Waste). "Different letters represent significant differences $(\mathrm{P} \leq \mathbf{0 . 0 5})$. Error bars are calculations of standard error.

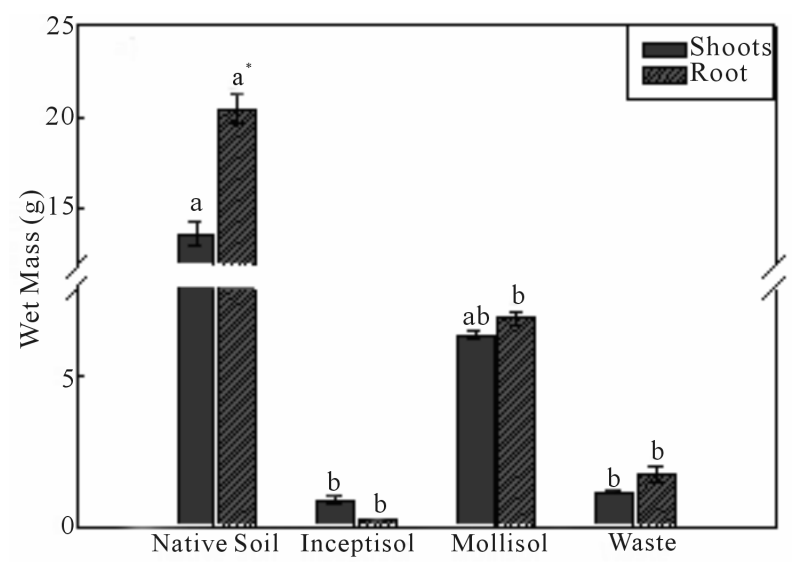

(a)

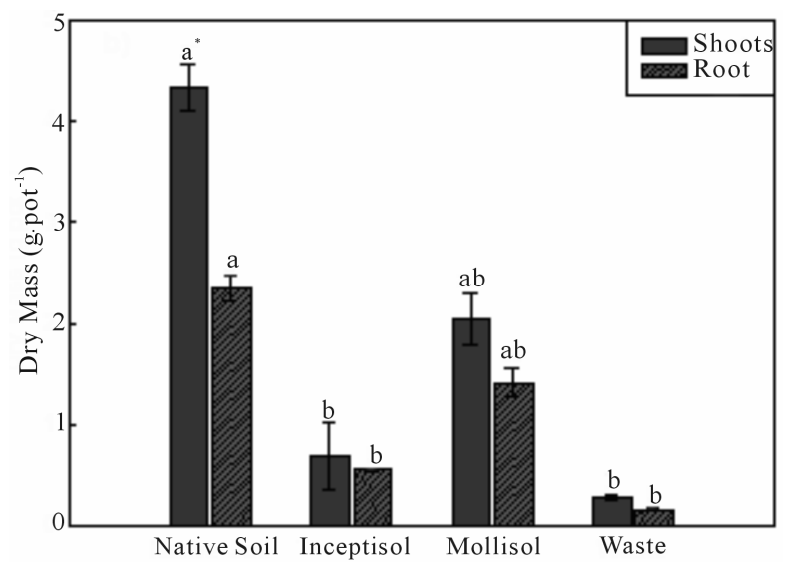

(b)

Figure 3. Wet mass (a) and dry mass (b) of the shoots and roots of Brachiaria decumbens plants after 47 days growing in different copper contaminated soils: Native soil (Control); Inceptisol; Mollisol and copper mining waste (Waste). "Different letters represent significant differences $(P \leq 0.05)$. Error bars are calculations of standard error. 
roots ( 2 and $1.4 \mathrm{~g} \cdot \operatorname{pot}^{-1}$, respectively), having biomass production significantly high compared with the control

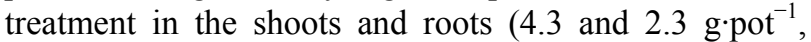
respectively). Both Inceptisol and copper mining waste exhibited the same level of growth with values of the dry biomass of the shoot of 0.68 and $0.28 \mathrm{~g} \cdot \mathrm{pot}^{-1}$, respectively.

\subsection{Uptake of Macro- and Micronutrient}

The macronutrient uptake of the Brachiaria decumbens was affected after 47 days of growth in different copper contaminated soils in the shoots (Table 1) and roots (Table 2).

Brachiaria decumbens exhibited increased levels of macronutrient concentrations in the shoots, after growth in Inceptisol and copper mining waste, for P $(0.44$ and $0.20 \mathrm{~g} \cdot \mathrm{kg}^{-1}$, respectively), $\mathrm{K}\left(4.62\right.$ and $2.79 \mathrm{~g} \cdot \mathrm{kg}^{-1}$, respectively), $\mathrm{S}\left(0.85\right.$ and $0.50 \mathrm{~g} \cdot \mathrm{kg}^{-1}$, respectively), Ca (both soils with $\left.0.72 \mathrm{~g} \cdot \mathrm{kg}^{-1}\right)$ and $\mathrm{Mg}(0.77$ and 0.58 $\mathrm{g} \cdot \mathrm{kg}^{-1}$, respectively) (Table 1). The $\mathrm{N}$ concentration in the shoots increased 3-fold in the Brachiaria plants after growth on copper mining waste with $3.01 \mathrm{~g} \cdot \mathrm{kg}^{-1}$ (Table 1) and in the roots with $1.64 \mathrm{~g} \cdot \mathrm{kg}^{-1}$ (Table 2) compared to the others treatments.

In general, vineyard soils and copper mining waste ex-

Table 1. Macronutrients in dry mass of the shoots of the Brachiaria decumbens plants, after growing in different copper contaminated soils: Native soil (Control, no contaminated); Inceptisol; Mollisol and copper mining waste (waste).

\begin{tabular}{|c|c|c|c|}
\hline & $\mathbf{N}$ & $\mathbf{P}$ & $\mathbf{K}$ \\
\hline & ----------- & $\mathrm{g} \cdot \mathrm{kg}^{-1}$ & \\
\hline Native Soil & $0.82 \pm 0.02 b^{*}$ & $0.06 \pm 0.00 b$ & $1.76 \pm 0.02 \mathrm{a}$ \\
\hline Inceptisol & $0.74 \pm 0.01 b$ & $0.44 \pm 0.01 \mathrm{a}$ & $4.62 \pm 0.11 \mathrm{a}$ \\
\hline Mollisol & $0.74 \pm 0.09 b$ & $0.25 \pm 0.02 \mathrm{ab}$ & $1.89 \pm 0.17 \mathrm{a}$ \\
\hline Waste & $3.01 \pm 0.16 \mathrm{a}$ & $0.20 \pm 0.04 \mathrm{ab}$ & $2.79 \pm 0.54 \mathrm{a}$ \\
\hline \multirow[t]{2}{*}{$\mathrm{CV}(\%)^{* *}$} & 29.03 & 51.63 & 40.09 \\
\hline & $\mathbf{S}$ & $\mathrm{Ca}$ & Mg \\
\hline Native Soil & $0.11 \pm 0.00 \mathrm{a}$ & $0.35 \pm 0.01 b$ & $0.23 \pm 0.00 \mathrm{~b}$ \\
\hline Inceptisol & $0.85 \pm 0.02 \mathrm{a}$ & $0.72 \pm 0.01 \mathrm{a}$ & $0.77 \pm 0.00 \mathrm{a}$ \\
\hline Mollisol & $0.11 \pm 0.01 \mathrm{a}$ & $0.34 \pm 0.01 b$ & $0.46 \pm 0.02 b$ \\
\hline Waste & $0.50 \pm 0.03 \mathrm{a}$ & $0.72 \pm 0.01 \mathrm{a}$ & $0.58 \pm 0.11 \mathrm{ab}$ \\
\hline $\mathrm{CV}(\%)$ & 94.18 & 28.70 & 26.49 \\
\hline
\end{tabular}

*Values are means \pm standard error of the mean. Different letters in the column represent significant differences $\left(\mathrm{P} \leq 0.05\right.$-Tuckey test). ${ }^{* *} \mathrm{CV}$ is the coefficient of variation of the means.
Table 2. Macronutrients in dry mass of the roots of the Brachiaria decumbens plants, after growing in different copper contaminated soils: Native soil (Control, no contaminated); Inceptisol; Mollisol and copper mining waste (waste).

\begin{tabular}{|c|c|c|c|}
\hline & $\mathbf{N}$ & $\mathbf{P}$ & $\mathbf{K}$ \\
\hline & \multicolumn{3}{|c|}{ - } \\
\hline Native Soil & $0.70 \pm 0.01 b^{*}$ & $0.05 \pm 0.00 \mathrm{~b}$ & $1.26 \pm 0.07 \mathrm{a}$ \\
\hline Inceptisol & $0.80 \pm 0.01 \mathrm{~b}$ & $0.18 \pm 0.02 \mathrm{a}$ & $1.86 \pm 0.28 \mathrm{a}$ \\
\hline Mollisol & $0.78 \pm 0.01 \mathrm{~b}$ & $0.12 \pm 0.01 \mathrm{a}$ & $1.06 \pm 0.05 \mathrm{a}$ \\
\hline Waste & $1.64 \pm 0.01 \mathrm{a}$ & $0.07 \pm 0.01 \mathrm{~b}$ & $1.88 \pm 0.08 \mathrm{a}$ \\
\hline \multirow[t]{2}{*}{$\mathrm{CV}(\%)^{* *}$} & 14.35 & 32.03 & 39.33 \\
\hline & $\mathbf{S}$ & $\mathbf{C a}$ & Mg \\
\hline Native Soil & $0.30 \pm 0.01 \mathrm{ab}$ & $0.25 \pm 0.01 \mathrm{~ns}$ & $0.28 \pm 0.01 \mathrm{~ns}$ \\
\hline Inceptisol & $0.55 \pm 0.00 \mathrm{a}$ & $1.10 \pm 0.19$ & $0.63 \pm 0.02$ \\
\hline Mollisol & $0.14 \pm 0.02 \mathrm{~b}$ & $0.21 \pm 0.01$ & $0.42 \pm 0.02$ \\
\hline Waste & $0.31 \pm 0.00 \mathrm{ab}$ & $0.31 \pm 0.01$ & $0.36 \pm 0.03$ \\
\hline $\mathrm{CV}(\%)$ & 43.80 & 81.07 & 32.09 \\
\hline
\end{tabular}

*Values are means \pm standard error of the mean. Different letters in the column represent significant differences $(\mathrm{P} \leq 0.05$-Tuckey test $) .{ }^{* *} \mathrm{CV}$ is the coefficient of variation of the means.

habited increased levels of macronutrient concentrations in the roots of $B$. decumbens plants after 47 days of growth (Table 2). Macronutrient concentrations in the roots of $B$. decumbens plants were high when grown in the Inceptisol for P $\left(0.18 \mathrm{~g} \cdot \mathrm{kg}^{-1}\right), \mathrm{K}\left(1.86 \mathrm{~g} \cdot \mathrm{kg}^{-1}\right), \mathrm{S}(0.55$ $\left.\mathrm{g} \cdot \mathrm{kg}^{-1}\right), \mathrm{Ca}\left(1.1 \mathrm{~g}^{\mathrm{kg}} \mathrm{kg}^{-1}\right)$ and $\mathrm{Mg}\left(0.63 \mathrm{~g} \cdot \mathrm{kg}^{-1}\right)$. When $B$. decumbens grew in the copper mining waste treatment plant roots exhibited only the high levels of the macronutrient concentrations for $\mathrm{N}, \mathrm{K}$ and $\mathrm{S}$ with values of $1.64,1.88$ and $0.31 \mathrm{~g} \cdot \mathrm{kg}^{-1}$, respectively. However, Mollisol vineyard soil only exhibited superior $\mathrm{P}$ concentrations in the roots than other treatments with $0.12 \mathrm{~g} \cdot \mathrm{kg}^{-1}$, and significantly equal to $\mathrm{P}$ concentrations of $B$. decumbens plants grew in Inceptisol with $0.18 \mathrm{~g} \cdot \mathrm{kg}^{-1}$.

Brachiaria decumbens plants grown in Inceptisol also increased micronutrients uptake in the shoots and roots (Table 3). Growth of B. decumbens plants exhibited the highest concentrations levels of $\mathrm{Zn}, \mathrm{Mn}$ and $\mathrm{Na}$ in the roots and shoots in Inceptisol soil treatment. Plants exhibited $\mathrm{Zn}$ concentrations in the biomass of the shoots and roots values of 472 and $1137 \mathrm{mg} \cdot \mathrm{kg}^{-1}$, respectively. In the same Inceptisol, plants exhibited Mn concentrations of 227 and $325 \mathrm{mg} \cdot \mathrm{kg}^{-1}$ in the shoots and roots, respectively; sodium concentrations were high in both shoots $\left(1276 \mathrm{mg} \cdot \mathrm{kg}^{-1}\right)$ and roots $\left(1337 \mathrm{mg} \cdot \mathrm{kg}^{-1}\right)$, with the 
Table 3. Micronutrients in dry mass of the shoots and roots of the Brachiaria decumbens plants, after growing in different copper contaminated soils: Native soil (Control, no contaminated); Inceptisol; Mollisol and copper mining waste (waste), and translocation factor (TF).

\begin{tabular}{|c|c|c|c|c|}
\hline & \multicolumn{4}{|c|}{ Shoots } \\
\hline & $\mathrm{Zn}$ & $\mathrm{Fe}$ & $\mathrm{Mn}$ & $\mathrm{Na}$ \\
\hline & & \multicolumn{2}{|c|}{ 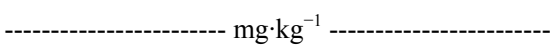 } & \\
\hline Native Soil & $47.52 \pm 1.92 b^{*}$ & $175.53 \pm 8.20 \mathrm{~b}$ & $195.63 \pm 11.07 \mathrm{a}$ & $336.90 \pm 11.7 \mathrm{a}$ \\
\hline Inceptisol & $472.45 \pm 22.8 \mathrm{a}$ & $680.35 \pm 27.3 b$ & $227.50 \pm 22.80 \mathrm{a}$ & $1276.15 \pm 231.4 \mathrm{a}$ \\
\hline Mollisol & $126.37 \pm 5.04 \mathrm{~b}$ & $166.30 \pm 11.2 b$ & $63.67 \pm 3.57 \mathrm{a}$ & $283.90 \pm 28.5 \mathrm{a}$ \\
\hline Waste & $90.93 \pm 39.2 b$ & $2683.00 \pm 51.6 \mathrm{a}$ & $242.90 \pm 48.14 \mathrm{a}$ & $1059.15 \pm 463.8 \mathrm{a}$ \\
\hline \multirow[t]{3}{*}{$\mathrm{CV}(\%)^{* *}$} & 74.99 & 35.31 & 50.88 & 75.07 \\
\hline & \multicolumn{4}{|c|}{ Roots } \\
\hline & $\mathrm{Zn}$ & $\mathrm{Fe}$ & $\mathrm{Mn}$ & $\mathrm{Na}$ \\
\hline Native Soil & $62.13 \pm 1.06 \mathrm{~b}$ & $3905.25 \pm 159.7 \mathrm{~ns}$ & $626.05 \pm 17.4 \mathrm{a}$ & $754.20 \pm 19.0 \mathrm{a}$ \\
\hline Inceptisol & $1137.00 \pm 17.9 \mathrm{a}$ & $2282.00 \pm 154.6$ & $325.05 \pm 0.26 \mathrm{ab}$ & $1337.05 \pm 178.2 \mathrm{a}$ \\
\hline Mollisol & $297.95 \pm 15.7 b$ & $2700.00 \pm 24.50$ & $202.67 \pm 16.9 \mathrm{~b}$ & $812.47 \pm 39.6 \mathrm{a}$ \\
\hline Waste & $44.70 \pm 11.0 \mathrm{~b}$ & $3134.50 \pm 201.2$ & $115.55 \pm 3.71 \mathrm{~b}$ & $1320.50 \pm 48.4 \mathrm{a}$ \\
\hline \multirow[t]{2}{*}{$\mathrm{CV}(\%)$} & 66.09 & 70.05 & 69.02 & 117.02 \\
\hline & $\mathrm{Zn}(\mathrm{TF})^{* * *}$ & $\mathrm{Fe}(\mathrm{TF})$ & $\operatorname{Mn}(\mathrm{TF})$ & $\mathrm{Na}(\mathrm{TF})$ \\
\hline Native Soil & 0.76 & 0.04 & 0.45 & 0.45 \\
\hline Inceptisol & 0.42 & 0.30 & 0.70 & 0.95 \\
\hline Mollisol & 0.42 & 0.06 & 0.31 & 0.35 \\
\hline Waste & 2.03 & 0.86 & 2.10 & 0.80 \\
\hline
\end{tabular}

*Values are means \pm standard error of the mean. Different letters in the column represent significant differences $(\mathrm{P} \leq 0.05-$ Tuckey test $) .{ }^{* *} \mathrm{CV}$ is the coefficient of variation of the means.

highest translocation factor (TF) value (0.95) from the roots to shoots among the treatments. Copper mining waste exhibited the highest Fe concentrations among the copper contaminated soils in the shoots and roots biomass with 2683 and $3134 \mathrm{mg} \cdot \mathrm{kg}^{-1}$, respectively (Table 3).

Also, after plants grown in copper mining waste, $\mathrm{Mn}$ concentrations in the shoots $\left(242 \mathrm{mg} \cdot \mathrm{kg}^{-1}\right)$ and $\mathrm{Na}$ concentrations in the shoots and roots were highlighted with values of 1059 and $1320 \mathrm{mg} \cdot \mathrm{kg}^{-1}$, respectively (Table 3). The highest values of TF were obtained in the copper mining waste treatment, either for $\mathrm{Zn}, \mathrm{Fe}$ and $\mathrm{Mn}$ with values of 2.03, 0.86 and 2.10, respectively.

\subsection{Copper phytoextraction and phytoextraction}

Brachiaria decumbens exhibited high copper phytoextraction by roots in all copper contaminated soils (Figure
4).

Plants cultivated in the Inceptisol exhibited the highest copper phytoextraction in the shoots, roots and entire plant with values of copper concentration in the biomass of 70,585 and $655 \mathrm{mg} \cdot \mathrm{kg}^{-1}$, respectively. Also, the other vineyard soil (Mollisol) exhibited greatest values with Brachiaria growing on copper contaminated soil. Brachiaria plants phytoextracted copper from Mollisol and accumulated high levels in the roots and entire plant (353 and $371 \mathrm{mg} \cdot \mathrm{kg}^{-1}$, respectively). Furthermore, phytoextraction was substantial high from copper mining waste with Brachiaria plants and accumulation was high in the roots and entire plant with of 414 and $466 \mathrm{mg} \cdot \mathrm{kg}^{-1}$, respectively. The (TF) of Brachiaria plants for copper exhibited low indexes for both vineyard soils (Inceptisol and Mollisol) and copper mining waste, with values of $0.12,0.05$ and 0.12 , respectively (Figure 4). On the other hand, Brachiaria decumbens plants exhibited high bio 


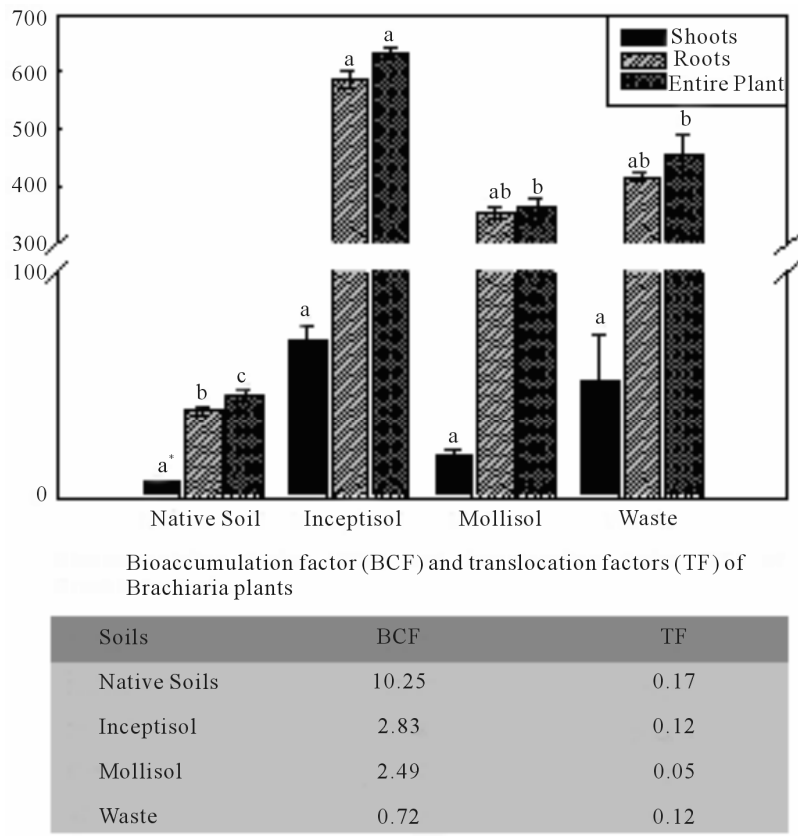

Figure 4. Copper concentrations in the shoots, roots and total copper bioaccumulated by Brachiaria decumbens plants in different copper contaminated soils: Native soil (Control); Inceptisol; Mollisol and copper mining waste (waste). Error bars are calculations of standard error. "Different letters in the same color bars, represent significant differences $(P \leq 0.05)$. Table express bioaccumulation factor (BCF) and translocation factors (TF).

accumulation factor (BCF) in both vineyard soils (Inceptisol and Mollisol) contaminated with copper with values of 2.83 and 2.49 , respectively.

Brachiaria plants phytoextracted high quantities of copper in all treatments contaminated with copper (Figure 5). Brachiaria submitted to Inceptisol treatment, a 40year-old vineyard soil contaminated with high copper concentrations, exhibited the highest potential for $\mathrm{Cu}$ phytoextraction, with more than $3157 \mathrm{~g} \cdot \mathrm{ha}^{-1}$ of $\mathrm{Cu}$ phytoextracted. B. decumbens grown in Mollisol soil and copper mining waste showed the same levels, and also presented high potential for copper phytoextraction, with values of 1824 and $2271 \mathrm{~g} \cdot \mathrm{ha}^{-1}$, respectively (Figure 5).

\section{Discussion}

The plant dysfunction due an excess of heavy metals can be observed at the morphological levels, such as low biomass production. Furthermore, high copper concentrations can affect growth, nutrition, root morphology, and distribution of $\mathrm{Cu}$ in roots of other grass plant as Sabi grass (Urochloa mosambicensis) [29]. Normally, Brachiaria decumbens shows a high biomass production and a remarkable resistance to high levels of aluminum in the soils [30]. Also, this specie can support extremely hard conditions such as high heavy metals concentrations

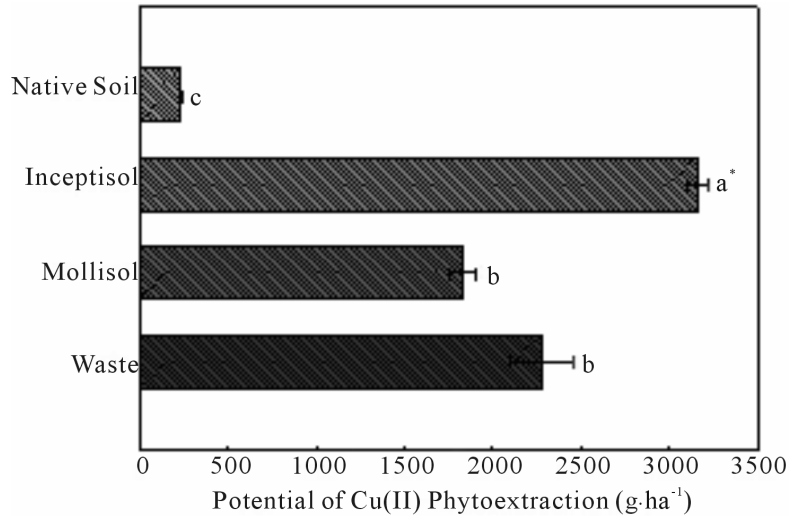

Figure 5. Copper concentrations in the shoots, roots and total copper bioaccumulated by Brachiaria decumbens plants in different copper contaminated soils: Native soil (Control); Inceptisol; Mollisol and copper mining waste (waste). Error bars are calculations of standard error. "Different letters in the same color bars, represent significant differences $(\mathrm{P} \leq \mathbf{0 . 0 5})$. Table express bioaccumulation factor (BCF) and translocation factors (TF).

into soils and still shows a substantial growth [12]. It shows successful and useful characteristics for phytoremediation and phytostabilization purposes, since this specie is strongly resistant to hardly field conditions. High biomass production by $B$. decumbens was observed in soils with high concentrations of $\mathrm{Pb}, \mathrm{Zn}$ and $\mathrm{Cd}$, which showed biomasses weight ranged from 0.81 to 1.89 $\mathrm{g} \cdot \operatorname{pot}^{-1}[12]$. It demonstrates a high potential of growth of Brachiaria species in heavy metal polluted soils.

High copper concentrations can produce different effects on plants growth $[31,32]$. For example, cucumber leaves showed a reduction in leaf area, while mature leaves exhibited a significant decline in photosynthesis after $\mathrm{Cu}$ addition in nutrient solution, also the sucrose and starch content were rose in both mature and immature leaves [31]. The Sabi grass, after 10 days of growth in diluted nutrient solutions in the two lowest $\mathrm{Cu}$ treatments $(0.12$ and $0.28 \mu \mathrm{M}$ of $\mathrm{Cu}(\mathrm{II})$, or 0.0076 and 0.0178 $\mathrm{mg} \cdot \mathrm{L}^{-1}$ of $\mathrm{Cu}(\mathrm{II})$, respectively), plants were healthy in appearance and grew vigorously producing approximately $3 \mathrm{~g}$ of the shoots and roots (fresh mass) during 10 days of experimental period [29].

High copper concentration can affect nutrient uptake, and accumulation in the plant biomass such as occurred in oatmeal (Avena sativa) plants after growth in copper contaminated soils [25]. In the same way, Convolvulus arvensis increased $\mathrm{P}$ and $\mathrm{K}$ uptake, and accumulation in the both shoots and roots of plants after 15 days of growth in agar-based media spiked with $20 \mathrm{mg} \cdot \mathrm{L}^{-1}$ of copper [9]. In the same study, among the micronutrients (B, Fe, Mo, Mn and Zn), only Fe concentrations in both shoots and roots increased after Convolvulus arvensis growth in this medium. However, in other study with 
nutrient distribution in the roots, Brachiaria brizantha showed dependence on $\mathrm{K}$ and $\mathrm{Cl}$, and it showed a certain extent to $\mathrm{Mn}$ in the apex (area of root cap), but since Mn is a micronutrient, its weight to this dependence is not as relevant as $\mathrm{K}$ and $\mathrm{Cl}$, [33].

Copper induced chlorosis could thus be mediated by its effect on iron mobility within the plant [34]. In an experiment with Phaseolus vulgaris, this plant showed reduction on $\mathrm{Fe}, \mathrm{K}$ and $\mathrm{Zn}$ ion contents in expanding leaves from seedlings exposed to $5 \mathrm{mg} \cdot \mathrm{L}^{-1}$ of copper in the nutrient solution [35]. However, copper exposure affects water flux and ion path in rice (Oryza sativa) seedlings, while the excess of copper decreased the water flux of rice seedlings and copper upward transport increased steadily with time [36]. In other grass plant (Urochloa mosambicensis), with high biomass production, the micronutrient uptake was significantly decreased in the shoot for $\mathrm{Fe}, \mathrm{Zn}$, and $\mathrm{Mn}$; concentrations of these three elements tended to increase, although not significantly, in the root tissue after growth in a 0.12 $\mathrm{mg} \cdot \mathrm{L}^{-1}$ of $\mathrm{Cu}$ (II) containing solution [29]. This copper exposure displayed an obvious interveinal chlorosis, consistent with $\mathrm{Cu}$-induced Fe deficiency, and also, tissue analysis revealed that increasing $\mathrm{Cu}$ (II) concentration resulted in significant decreases in tissue concentrations of $\mathrm{K}$ and $\mathrm{Mg}$ in the both shoots and roots of this specie [29]. Brachiaria decumbens plants did not show any visual symptoms of toxicity or chlorosis after grown in the vineyard copper contaminated soils and copper mining waste, demonstrating a resistance capacity to growth in copper contaminated soils.

The term "phytoextraction" mainly concerns the removal of heavy metals or radionuclides from soil by means of the uptake capabilities of plants [5]. Plants can accumulate essential heavy metals such as Fe, Mn, Zn, $\mathrm{Cu}, \mathrm{Mo}$, and possibly $\mathrm{Ni}$ for its growth and development [5]. In our experiment, B. decumbens exhibited a high capacity of copper phytoextraction in the entire biomass, mainly in the roots. In other experiment, this specie showed high capacity for $\mathrm{Pb}, \mathrm{Cd}$ and $\mathrm{Zn}$ phytoextraction from heavy metal contaminated soil [12]. It demonstrates the high potential of this specie for heavy metals phytoremediation of contaminated soils.

The transport of copper in plants is limited; therefore, the highest concentrations are often in root tissues [37]. Other plants such as Cyperus esculentus and Phyla nodiflora both with TF values of 0.13 [27] also exhibited low TF for copper, when grown in high copper contaminated sites. In the same study, these species also showed low BCF, with values of 0.50 and 0.24 for Cyperus esculentus and Phyla nodiflora, respectively. Results demonstrated in this study, showed that Brachiaria decumbens has a higher $\mathrm{TF}$ and $\mathrm{BCF}$, than the literature [27]. It shows a high potential of $B$. decumbens for copper bioaccumulation in the copper contaminated soils, such as vineyards and copper mining waste.

In the tropical regions of Brazil, there are at least 80 million ha of pastures cultivated with grasses introduced from Africa, mainly with Brachiaria spp [38]. Brachiaria species for pasture have high biomass production. In the literature Brachiaria decumbens can produce up to 1800 $\mathrm{kg} \cdot \mathrm{ha}^{-1}$ grown in hard conditions of water deficiency, such as savannas [22]. The same species can produce in normal conditions with optimum addition of fertilizers around $3500 \mathrm{~kg} \cdot \mathrm{ha}^{-1}$ [39], and $9000 \mathrm{~kg} \cdot \mathrm{ha}^{-1}$ [40] of dry mass. Other specie Brachiaria brizantha can produce high quantities of biomass values between $3000 \mathrm{~kg} \cdot \mathrm{ha}^{-1}$ [41] and $8000 \mathrm{~kg} \cdot \mathrm{ha}^{-1}$ of dry biomass [42]; Brachiaria dictyoneura can produce more than $5700 \mathrm{~kg} \cdot \mathrm{ha}^{-1}$ when this crop is grown alone, without consortium [43]. For our purposes, we calculated the potential of copper phytoextraction by Brachiaria decumbens with a mean value of $5000 \mathrm{~kg} \cdot \mathrm{ha}^{-1}$ of phytomass production.

Phytostabilization of metals using trees or other perennial species is often promoted and can be an important strategy to control heavy metals polluted sites [20]. Thereby, phytostabilization use plants to reduce the bioavailability of pollutants in the environment and stabilize pollutants in soils, thus rendering their harmless and reducing the risk of further environmental degradation by leaching of pollutants into the ground water or by airborne spread [5]. Brachiaria decumbens plants showed high capacity of growth and copper phytoaccumulation in the roots after growth in copper contaminated soils. These characteristics are very important for phytostabilization. Furthermore, vineyard soils in Brazil are generally found in steep mountains, and lands with difficult access by mechanical equipments, and the soil removal can be an inappropriate, and a high cost option to the vineyard. Thus, the phytostabilization with plant species with high potential of copper accumulation could be the most suitable and feasible solution for remediation of these copper contaminated areas.

The translocation of heavy metals from the roots to shoots is important for phytoremediation when the shoots are easily harvested. Although, the copper in the roots of Brachiaria plants was high, copper phytoextraction can be more efficient with Brachiaria plants when the entire plant is harvested. In the copper mining area, this practice can be very useful, because of the characteristics of these areas such as unstructured, wide and plan with low soil loss by erosion, the removal of the total plant can be made mechanically and cost-friendly to the environment. However, for vineyard areas, the terrain is one of the most problematic in these areas, together with the vineyard, where plants are with high implementation and 
cultivation costs, and several years is necessary to produce wines with high quality. In these areas, Brachiaria decumbens can be used for phytostabilization. Brachiaria decumbens showed high $\mathrm{Cu}$ concentrations in the biomass being an effective plant for copper complexation and stabilization in these areas. The use of Brachiaria decumbens can reduces the losses of copper contaminated soil by surface runoff, mitigating the negative impact on water quality; furthermore, the important role of the $\mathrm{Cu}$ phytostabilization by Brachiaria decumbens, can promote the reduction of the copper leaching in the soil profile, contributing to water quality protection. Moreover, the transportation fuel based on cellulosic biomass can offer an attractive alternative for energy source; Brachiaria grown for heavy metal remediation might be used to produce bioenergy, being one more possible alternative to reduce the heavy metal impact on soil, removing it from soil and producing clean energy.

\section{Conclusion}

Brachiaria decumbens plant exhibited high capacity copper phytoextraction in a vineyard soils and copper mining waste by entire plant. Brachiaria plants did not show substantial depletion on macronutrient uptake, or any nutrient deficiency after growth in the copper contaminated soils. Also, this plant exhibited greatest phytostabilization characteristics such as high shoots and roots biomass production, and high copper bioaccumulation in the roots. For all characteristics summarized, Brachiaria decumbens can be an important tool for copper phytoremediation in the copper contaminated vineyard soils and copper mining waste, reducing copper contamination of adjacent areas, contributing to protecting the water quality and the environment, removing it from soil and producing clean energy.

\section{Acknowledgements}

This Project was supported by CAPES (Coordenação de Aperfeiçoamento de Pessoal de Nível Superior) and CNPq (Conselho Nacional de Desenvolvimento Científico e Tecnológico), Brazil. Thanks to Marcelo Gioacometti, Guilherme Siviero and Dione D. Rohers for technical assistance.

\section{REFERENCES}

[1] A. V. Geen and S. N. Luoma, "The Impact of Human Activities on Sediments of San Francisco Bay, California: An Overview," Marine Chemistry, Vol. 64, No. 1-2, 1999, pp. 1-6. http://dx.doi.org/10.1016/S0304-4203(98)00080-2

[2] A. E. Alnenaei and M. Authman, "Impact of Human Activities on Aluminum Contamination in the Drainage Ca- nals in the Nile Delta, Egypt," Abstracts/Toxicology Letters, Vol. 1, No. 1, pp. S337-S351. http://dx.doi.org/10.1051/e3sconf/20130111004

[3] H. Zhang and B. Shan, "Historical Records of Heavy Metal Accumulation in Sediments and the Relationship with Agricultural Intensification in the Yangtze-Huaihe Region, China," Science of the Total Environment, Vol. 399, No. 1-3, 2008, pp. 113-120.

http://dx.doi.org/10.1016/j.scitotenv.2008.03.036

[4] L. Laybauer, "Incremento de Metais Pesados na Drenagem Receptora de EFLUENTEs de Mineração-Minas do Camaquã, Sul do Brasil," Revista Brasileira de Recursos Hídricicos, Vol. 3, No. 3, 1998, pp. 29-36.

[5] C. Garbisu and I. Alkorta, "Phytoextraction: A Cost-Effective Plant-Based Technology for the Removal of Metals from the Environment," Bioresource Technology, Vol. 77, No. 3, 2001, pp. 229-236. http://dx.doi.org/10.1016/S0960-8524(00)00108-5

[6] S. C. McCutcheon and J. L. Schnoor, "Phytoremediation: Transformation and Control of Contaminants," WileyInterscience, Hoboken, 2003.

[7] Z. Fischerová, P. Tlustos, J. Száková and K. Sichorova, "A Comparison of Phytoremediation Capability of Selected Plant Species for Given Trace Elements," Environmental Pollution, Vol. 144, No. 1, 2006, pp. 93-100. http://dx.doi.org/10.1016/i.envpol.2006.01.005

[8] L. Raskin., R. D. Smith and D. E. Salt, "Phytoremediation of Metals: Using Plants to Remove Pollutants from the Environment," Current Opinion in Biotechnology, Vol. 8, No. 1, 1997, pp. 221-226. http://dx.doi.org/10.1016/S0958-1669(97)80106-1

[9] J. L. Gardea-Torresdey, J. R. Peralta-Videa, M. Montes, G. Rosa and B. Corral-Diaz, "Bioaccumulation of Cadmium, Chromium and Copper by Convolvulus arvensis L.: Impact on Plant Growth and Uptake of Nutritional Elements," Bioresource Technology, Vol. 92, No. 3, 2004, pp. 229-235.

http://dx.doi.org/10.1016/j.biortech.2003.10.002

[10] R. Clemente, C. Almela and M. P. Bernal, "A Remediation Strategy Based on Active Phytoremediation Followed by Natural Attenuation in a Soil Contaminated by Pyrite Waste," Environmental Pollution, Vol. 143, No. 3, 2006, pp. 397-406.

[11] C. Mant, S. Costa, J. Williams and E. Tambourgi, "Phytoremediation of Chromium by Model Constructed Wetland," Bioresource Technology, Vol. 97, No. 15, 2006, pp. 1767-1772. http://dx.doi.org/10.1016/j.biortech.2005.09.010

[12] F. S. Santos, J. Hernández-Allica, J. M. Becerril, N. Amaral-Sobrinho, N. Mazur and C. Garbisu, "Chelate-Induced Phytoextraction of Metal Polluted Soils with Brachiaria decumbens," Chemosphere, Vol. 65, No. 1, 2006, pp. 43-50.

http://dx.doi.org/10.1016/j.chemosphere.2006.03.012

[13] S. Bose, J. Vedamati, V. Rai and A. L. Ramanathan, "Metal Uptake and Transport by Tyaha angustata L. Grown on Metal Contaminated Waste Amended Soil: An Implication of Phytoremediation," Geoderma, Vol. 145, 
No. 1-2, 2008, pp. 136-142.

http://dx.doi.org/10.1016/j.geoderma.2008.03.009

[14] A. Saifullah, E. Meers, M. Qadir, P. Caritat, F. M. G. Tack, D. G. Laing and M. H. Zia, "EDTA-Assisted Pb Phytoextraction," Chemosphere, Vol. 74, No. 10, 2008, pp. 1279-1291.

http://dx.doi.org/10.1016/j.chemosphere.2008.11.007

[15] R. Chandra and S. Yadav, "Potential of Typha angustifolia for Phytoremediation of Heavy Metals from Aqueous Solution of Phenol and Melanoidin," Ecological Engineering, Vol. 36, No. 10, 2010, pp. 1277-1284. http://dx.doi.org/10.1016/j.ecoleng.2010.06.003

[16] L. Buendia-Gonzalez, J. Orozco-Villafuerte, F. Cruz-Sosa, C. E. Barrera-Diaz and E. J. Vernon-Carter, "Prosopis laevigata a Potential Chromium (VI) and Cadmium (II) Hyperaccumulator Desert Plant," Bioresource Technology, Vol. 101, No. 15, 2010, pp. 5862-5867. http://dx.doi.org/10.1016/j.biortech.2010.03.027

[17] A. Ruttens, M. Mench, J. V. Colpaert, J. Boisson, R. Carleer and J. Vangronsveld, "Phytostabilization of a Metal Contaminated Sandy Soil. I: Influence of Compost and/or Inorganic Metal Immobilizing Soil Amendments on Phytotoxicity and Plant Availability of Metals," Environmental Pollution, Vol. 144, No. 2, 2006, pp. 524-532. http://dx.doi.org/10.1016/j.envpol.2006.01.038

[18] M. T. Domínguez, F. Madrid, T. Marañón and J. M. Murillo, "Cadmium Availability in Soil and Retention in Oak Roots: Potential for Phytostabilization," Chemosphere, Vol. 76, No. 4, 2009, pp. 480-486. http://dx.doi.org/10.1016/j.chemosphere.2009.03.026

[19] J. Kumpiene, G. Guerri, L. Landi, G. Pietramellara, P. Nannipieri and G. Renella, "Microbial Biomass, Respiration and Enzyme Activities after in Situ Aided Phytostabilization of a Pb- and Cu-Contaminated Soil," Ecotoxology and Environmental Safety, Vol. 72, No. 1, 2008, pp. 115-119. http://dx.doi.org/10.1016/j.ecoenv.2008.07.002

[20] L. V. Nevel, J. Mertens, J. Staelens, A. D. Schrijver, F. M. G. Tack, S. D. Neve, E. Meers and K. Verheyen, "Elevated $\mathrm{Cd}$ and $\mathrm{Zn}$ Uptake by Aspen Limits the Phytostabilization Potential Compared to Five Other Tree Species," Ecological Engineering, Vol. 37, No. 7, 2011, pp. 10721080. http://dx.doi.org/10.1016/j.ecoleng.2010.07.010

[21] P. Alvarenga, A. P. Gonçalves, R. M. Fernandes, A. Varennes, G. Vallini, E. Duarte and A. C. Cunha-Queda, "Organic Residues as Immobilizing Agents in Aided Phytostabilization: (I) Effects on Soil Chemical Characteristics," Chemosphere, Vol. 74, No. 10, 2009, pp. 12921300.

http://dx.doi.org/10.1016/i.chemosphere.2008.11.063

[22] J. J. San José, R. Bracho and N. Nikonova, "Comparison of Water Transfer as a Component of the Energy Balance in a Cultivated Grass (Brachiaria decumbens Stapf.) Field and a Savanna during the Wet Season of the Orinoco Llanos," Agricultural and Forest Meteorology, Vol. 90, No. 1-2, 1998, pp. 65-79. http://dx.doi.org/10.1016/S0168-1923(97)00092-0

[23] I. M. Rao, J. W. Miles and J. C. Granobles, "Differences in Tolerance to Infertile Acid Soil Stress among Germplasm Accessions and Genetic Recombinants of the Tro- pical Forage Grass Genus, Brachiaria," Field Crop Research, Vol. 59, No. 1, 1998, pp. 43-52. http://dx.doi.org/10.1016/S0378-4290(98)00106-3

[24] P. Wenzl, A. L. Chaves, J. E. Mayer, I. M. Rao and M. G. Nair, "Roots of Nutrient-Deprived Brachiaria Species Accumulate 1,3-Di-O-trans-feruloylquinic Acid," Phytochemistry, Vol. 55, No. 5, 2000, pp. 389-395. http://dx.doi.org/10.1016/S0031-9422(00)00350-2

[25] R. Andreazza, B. C. Okeke, M. R. Lambais, L. Bortolon, G. W. B. Melo and F. A. O. Camargo, "Bacterial Stimulation of Copper Phytoaccumulation by Bioaugmentation with Rhizosphere Bacteria," Chemosphere, Vol. 81, No. 9, 2010, pp. 1149-1154.

http://dx.doi.org/10.1016/j.chemosphere.2010.09.047

[26] V. J. C. H. Schouwvenberg and I. Walinge, "Methods of Analysis for Plant Material," Agriculture University, Wageningen, 1973.

[27] J. Yoon, X. Cao, Q. Zhou and L. Q. Ma, “Accumulation of $\mathrm{Pb}, \mathrm{Cu}$, and $\mathrm{Zn}$ in Native Plants Growing on a Contaminated Florida Site," Science of the Total Environment, Vol. 368, No. 2-3, 2006, pp. 456-464.

http://dx.doi.org/10.1016/j.scitotenv.2006.01.016

[28] G. Shi and Q. Cai, "Cadmium Tolerance and Accumulation in Eight Potential Energy Crops," Biotechnology Advances, Vol. 27, No. 5, 2009, pp. 555-561.

http://dx.doi.org/10.1016/j.biotechadv.2009.04.006

[29] P. M. Kopittke, C. J. Asher, F. P. C. Blamey and N. W. Menzies, "Toxic Effects of $\mathrm{Cu}^{2+}$ on Growth, Nutrition, Root Morphology, and Distribution of $\mathrm{Cu}$ in Roots of Sabi Grass," Science of the Total Environment, Vol. 407, No. 16, 2009, pp. 4616-4621. http://dx.doi.org/10.1016/j.scitotenv.2009.04.041

[30] F. Vinit-Dunand, D. Epron, B. Alaoui-Sossé and P. Badot, "Effects of Copper on Growth and on Photosynthesis of Mature and Expanding Leaves in Cucumber Plants," Plant Science, Vol. 163, No. 1, 2002, pp. 53-58. http://dx.doi.org/10.1016/S0168-9452(02)00060-2

[31] F. Vinit-Dunand, D. Epron, B. Alaoui-Sossé and P. Badot, "Effects of Copper on Growth and on Photosynthesis of Mature and Expanding Leaves in Cucumber Plants," Plant Science, Vol. 163, No. 1, 2002, pp. 53-58. http://dx.doi.org/10.1016/S0168-9452(02)00060-2

[32] B. Alaoui-Sossé, P. Genet, F. Vinit-Dunand, M. Toussaint, D. Epron and P. Badot, "Effect of Copper on Growth in Cucumber Plants (Cucumis sativus) and Its Relationships with Carbohydrate Accumulation and Changes in Ion Contents," Plant Science, Vol. 166, No. 5, 2004, pp. 1213-1218. http://dx.doi.org/10.1016/j.plantsci.2003.12.032

[33] C. A. Pineda-Vargas, V. M. Prozesky, W. J. Przybylowicz and J. E. Mayer, "Correspondence Analysis Evaluation of Linear Nutrient Distribution in Root Tips of the Tropical Forage Brachiaria brizantha," Nuclear Instruments and Methods in Physics Research Section B: Beam Interactions with Materials and Atoms, Vol. 181, No. 1-4, 2001, pp. 493-498.

http://dx.doi.org/10.1016/S0168-583X(01)00625-5

[34] W. Ke, Z. T. Xiong, S. Chen and J. Chen, "Effects of 
Copper and Mineral Nutrition on Growth, Copper Accumulation and Mineral Element Uptake in Two Rumex japonicus Populations from a Copper Mine and an Uncontaminated Field Sites," Environmental and Experimental Botany, Vol. 59, No. 1, 2007, pp. 59-67. http://dx.doi.org/10.1016/j.envexpbot.2005.10.007

[35] H. Bouazizi, H. Jouili, A. Geitmann and E. E. Ferjani, "Copper Toxicity in Expanding Leaves of Phaseolus vulgaris L.: Antioxidant Enzyme Response and Nutrient Element Uptake," Ecotoxology and Environmental Safety, Vol. 73, No. 6, 2010, pp. 1304-1308. http://dx.doi.org/10.1016/j.ecoenv.2010.05.014

[36] C. Chen, T. Chen, K. Lo and C. Chiu, "Effects of Proline on Copper Transport in Rice Seedlings under Excess Copper Stress," Plant Science, Vol. 166, No. 1, 2004, pp. 103-111. http://dx.doi.org/10.1016/i.plantsci.2003.08.015

[37] J. R. Peralta-Videa, J. L. Gardea-Torresdey, E. Gomez, K. J. Tiemann, J. G. Parsons and G. Carrillo, "Effect of Mixed Cadmium, Copper, Nickel and Zinc at Different pHs upon Alfalfa Growth and Heavy Metal Uptake," Environmental Pollution, Vol. 119, No. 3, 2002, pp. 291301. http://dx.doi.org/10.1016/S0269-7491(02)00105-7

[38] R. M. Boddey, R. Macedo, R. Tarré, E. Ferreira, O. C. Oliveira, C. P. Rezende, R. B. Cantarutti, J. M. Pereira, B. J. R. Alves and S. Urquiaga, "Nitrogen Cycling in Brachiaria pastures: The Key to Understanding the Process of Pasture Decline," Agriculture Ecosystem and the Environment, Vol. 103, No. 2, 2004, pp. 389-403. http://dx.doi.org/10.1016/j.agee.2003.12.010
[39] K. F. Gobbi, R. Garcia, A. F. G. Neto, O. G. Pereira, M. C. Ventrella and G. C., Rocha, "Características Morfológicas, Estruturais e Produtividade do Capim Braquiária e do Amendoim Forrageiro Submetidos ao Sombreamento," Revista Brasileira de Zootecnia, Vol. 38, No. 9, 2009, pp. $1645-1654$.

[40] A. F. Magalhães, A. J. V. Pires, G. G. P. Carvalho, F. F Silva, R. S. Sousa and C. M. Veloso, "Influência do Nitrogênio e Do Fósforo na Produção do Capim-Braquiária," Revista Brasileira de Zootecnia, Vol. 36, No. 5, 2007, pp. 1240-1246. http://dx.doi.org/10.1590/S1516-35982007000600004

[41] C. G. S. Benett, O. M. Yamashita, P. S. Koga and K. S. Silva, "Resposta da Brachiaria brizantha cv. Marandu a Diferentes Tipos de Adubação," Revista de Ciências Agro-Ambientais, Vol. 6, No. 1, 2008, pp. 13-20.

[42] F. C. L. Freitas, F. A. Ferreira, L. R. Ferreira, M. V. Santos and E. L. Agnes, "Cultivo Consorciado de Milho Para Silagem com Brachiaria brizantha no Sistema de Plantio Convencional," Planta Daninha, Vol. 23, No. 4, 2005, pp. 635-644. http://dx.doi.org/10.1590/S0100-83582005000400011

[43] W. Trujillo, M. J. Fisher and R. Lal, "Root Dynamics of Native Savanna and Introduced Pastures in the Eastern Plains of Colombia," Soil Tillage Research, Vol. 87, No. 1, 2006, pp. 28-38. http://dx.doi.org/10.1016/j.still.2005.02.038 